\title{
爪を有する二脚式ソフトロボットの開発* （爪とストッパーを利用したソフトロボットの方向転換について）
}

\author{
Development of Biped Soft Robot with Nail \\ (Turn Using Nail and Stopper for Biped Soft Robot)
}

\author{
Mami NISHIDA*1 \\ ${ }^{* 1}$ Kanto Gakuin Univ. Dept. of Mechanical Engineering \\ 1-50-1 Mutsuurahigashi, Kanazawa-ku, Yokohama-shi, kanagawa, 236-8501 Japan
}

In this paper, author show a flexible bipedal soft robot which consisted of a SMA(shape memory alloy) and a thin polyethylene plate with nail and stopper. Author proposed to the flexible biped robot which consisted of a SMA(shape memory alloy) and a thin polyethylene plate. This robot can move to front, the back, and a horizontal direction using nail by attaching a nail such as a beetle at the tip of a robot's legs (FFP actuator) of a drive. And the combination it is possible walking by making ON-OFF signal timing of output and input combination. Therefore, in order to realize a flexible biped robot, a mechanism and signal timing need to be harmonized. The ON-OFF switching timing, central to the control strategy to achieve walking behavior, is determined through experiments. The resulting soft walking robot weighs a mere $4.7 \mathrm{~g}$ (with a height of $67 \mathrm{~mm}$, length of $109 \mathrm{~mm}$, breadth of $58 \mathrm{~mm}$ ). The experimental results demonstrate the viability and utility of the soft biped walking robot based on FFP actuator and the control strategy to achieve walking behavior.

Key Words : Biped Soft Robot, SMA, Soft Body,ON-OFF Signal Timings, FFP Actuator

1. 緒

ロボットのボディに軽量柔軟材を採用し，必要最小限の信号処理で方向転換できるソフトロボットがあれば, その利用範囲は格段に広がる，たとえば，社会インフラの老朽化や自然災害の増加にともない，過剰な内外部の 様子を偵察することを目的に，ロボット全体の構造を軽量柔軟にできれば，脆弱な環境下で周囲の構造物と接触 した際に，対象物を傷つけることなく調査できるロボットが可能となる．従来から広く普及しているロボットの 基本となる構造部分は, 高剛性 (剛体リンクとモータ等の剛体アクチュエータ) を採用し, 高精度を保っている. その反面，構造が複雑で高価になり，重くなるという欠点がある．また，こうしたロボットは，非常に脆弱な環 境において, 対象を傷つける可能性がある上，脱落・落下による副次的な被害を生ずるおそれがある，そこで， 構造自体に柔軟な素材を利用し，簡素で軽量な構成で単純に制御できるソフトロボットを考える。これまでに， ソフトロボットの研究は多方面からおこなわれており，ハードロボットと比較して(1)構造が単純(2)軽量小型が可 能(3)形状変化に富む(4)周囲を傷つけない(5)生体適合性（biocompatibility）に優れているといったアドバンテージ

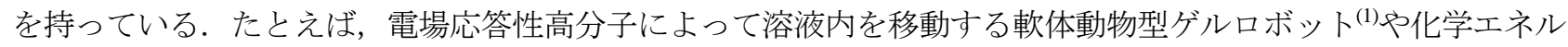
ギーを利用して自律歩行するケミカルゲルロボット ${ }^{(2)}$ ，低融点変態を利用した柔軟な脚を持つ自律的軟化変形ロ ボット ${ }^{(3)}$, 柔軟な形状変化が可能なテンセグリティ型の転がりロボット ${ }^{(4)}$, IPMCアクチュエータの伸縮で転がる 柔軟ロボット (5)などの研究がある. 近年（2012 年）では，ハーバード大学の Stephen A. Morin らが周囲の環境に 応じて擬態でき, 圧縮空気を使ってイカやタコがはうように動くシリコーンベースのソフトロボット ${ }^{(6)}$ を開発し

\footnotetext{
* 原稿受付 2013 年 8 月 3 日

*1 正員, 関東学院大学（广236-8501 神奈川県横浜市金沢区六浦東 1-50-1）

E-mail: mnishida@kanto-gakuin.ac.jp
} 
米科学誌サイエンス（Science）に発表された.このように，ソフトマシーンは近未来において新しい創造の可能 性を十分に予期している. しかしながら, 多くのソフトロボットは, 移動速度が遅く, 環境制限（特殊溶液中で の駆動）や動作制限（動作範囲が狭い）などの課題があり，メンテナンスが面倒で，壊れやすいく，扱いにくい などの側面がある. その上, 圧縮機を用いるなどの大掛かりな構造や複雑な制御を要するため, 実現化へ向けた 一歩が踏み出せていないのが現状である.

そこで, 構造と制御が単純で, 扱いやすい二脚式ソフトロボットの開発をおこなう. 筆者の先行研究で, 同素 材のポリエチレンプレートと SMA を組み合わせた四脚移動ロボットを提案している(7).このロボットは全長 $50[\mathrm{~mm}]$, 全幅 $45[\mathrm{~mm}]$, 全高 70[mm], 総質量 $5.7[\mathrm{~g}]$ と軽量, 小型, 柔軟を可能としている. また, 単純な ON-OFF 制御によって立脚した四本の脚を適切な信号タイミングで湾曲させることで, 前後移動, その場で旋回移動がで きる. 仮に, 四脚ロボット ( 4 入出力 4 脚駆動) から二脚ロボット（2 入出力 2 脚駆動）に形状変更できれば, よりシンプルな入出力信号で複数の動作（前後・左右・旋回動作モード）を実現できるだけでなく, 動力源を $1 / 2$ に減少させることができ, 省エネ低コスト生産などが可能となる. そこで, ロボットの駆動源である脚兼アクチ ユエータをスキー板のようにボディの外側へ左右水平に配置した腹ばい型の二脚式ソフトロボット ${ }^{(8)(9)}$ を提案し た. 本論文では, このロボットの先端部に, 薄板とメガネ端子を組み合わせた爪を固定し, ON-OFF信号タイミ ングによる薄板のたわみ量とボディ下部のストッパーを巧みに利用して, 2 入出力 2 脚駆動で前後, 左右旋回寸 るソフトロボットを開発する. 図 1 に製作した $4.7[\mathrm{~g}]$ の二脚式ソフトロボット(10)を示す. 本ロボットは, 図 2 の 例に示すように, 軽量小型であり, 特殊な溶液や大掛かりな装置も不要で組み立てやすく, 容易に大量生産でき る特徵がある. さらに, 耐熱性, 耐薬品性のポリエチレンプレートと SMA を採用しているため, 高温多湿な環 境下の埋設配管や小口径配管のような人間が直接検査できない狭險箇所での応用も期待できると考える. 本論で はまず，ロボットの概要について述べ，前後・左右旋回寸るための手法，並びにペイロードなどの基本的な移動 特性について報告する.
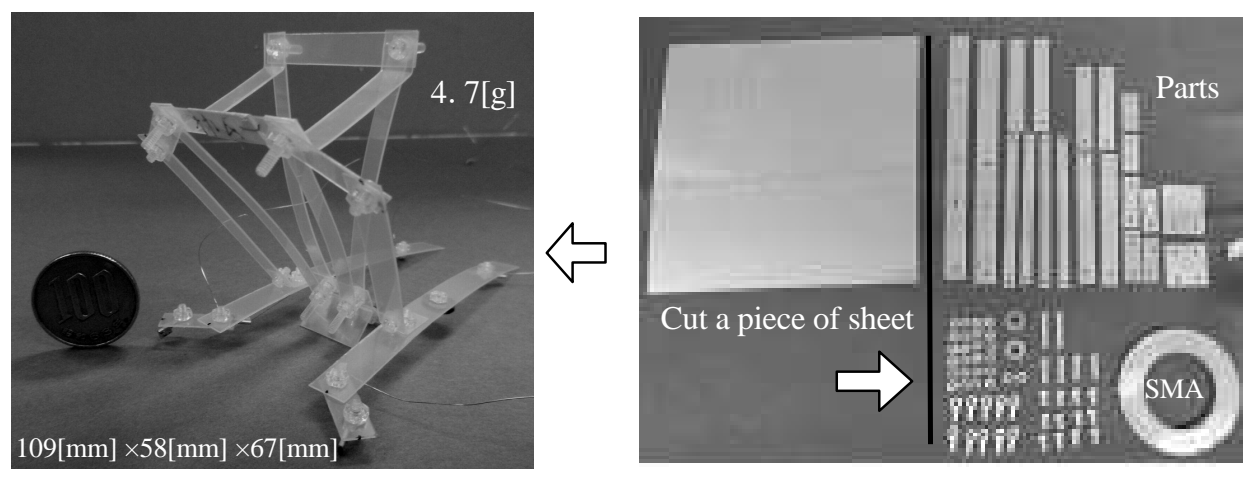

Fig.1 Trial manufacture development of biped soft robot

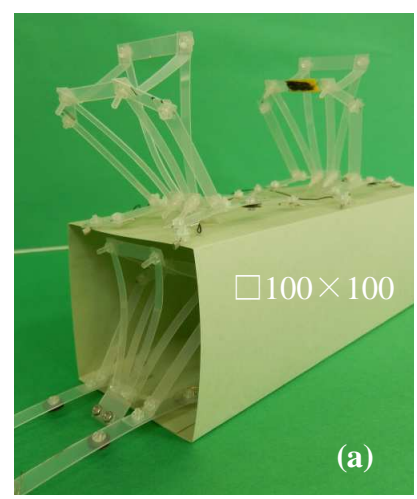

(a) a small inexpensive mass-produced

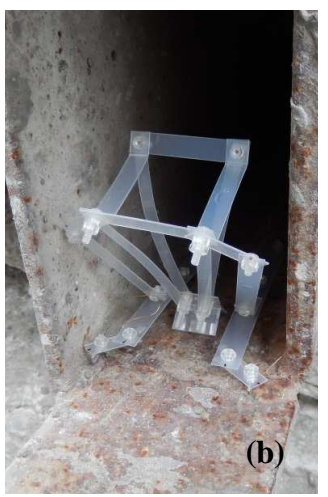

(b) narrow place

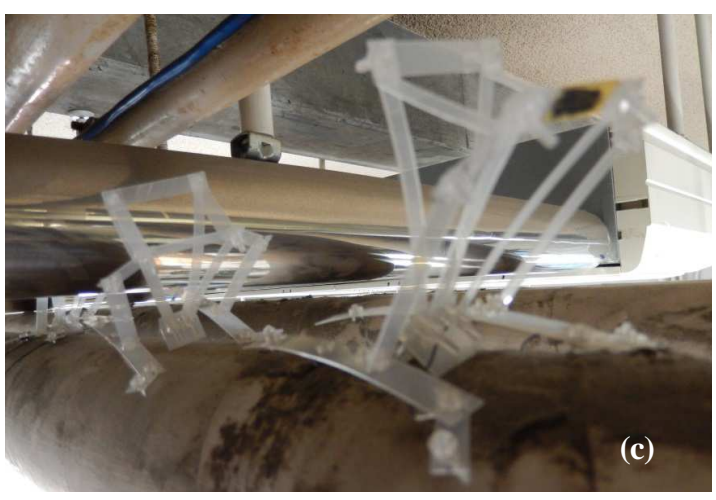

(c) a long and a place of especial vulnerability

Fig.2 Applied example of biped soft robot 


\section{2. 二脚式ソフトロボットの構成}

\section{$2 \cdot 1$ 設計思想}

足場が脆く，脆弱な環境を移動するには，周囲に損傷を与える心配のない安全性が要求される．これらの要求 を満足するためには，移動ロボット全体が柔軟であることが望ましい．また，将来的な応用を進めることを考え れば，本質的に小型化が容易な構造であるとよい，さらに，軽量にすることで，従来のロボットよりもエネルギ 一の低減が見込まれる。一般にロボットに用いられる材質は, 剛性が高く, 対象物と接触した際の接触力が大き い. それに比べ，柔軟リンクを用いたロボットはその柔軟性によってエネルギーを吸収でき，接触力を小さくす ることができる，一方で，素材が柔らかくなりすぎると強度を保つための何らかの補強が必要となり，結果的に 重量増となるだけでなく，変形量を制御することがより困難になる。これは，ロボットの移動アルゴリズムに大 きな影響を与え，移動や運搬などの行動に支障をきたす原因となる，本論では，このような条件を満足するため の一つの有力な方法として，弾性のある矩形薄板を逆四角錐台形に組み上げることで，ロボットの母体となるボ ディ中央の剛性を高め, 制御が簡単な SMA（形状記憶合金）と矩形板を組み合わせたアクチュエータを左右の駆 動源兼脚として配置することで, 簡単な ON-OFF 制御のみでロボットの移動を達成する. このように, 薄板の曲 げ要素と二值位拮抗型駆動源の組み合わせを利用して柔軟軽量かつ制御が簡単なロボットを開発する.

\section{$2 \cdot 2$ 設計方針}

剛体リンクおよび岡体アクチュエータで構成されたロボットは, 安定した精度と剛性が得られる一方，センサ 数が多数必要となり, 機構や制御の複雑化だけでなく, 大型・重量化など様々な問題が生じる. これに対して, 軟体リンクおよび柔体アクチュエータで構成されたロボットは, 部品点数を極力少なくし， ロボットの構造材料 と駆動源とを一体化することによって，よりシンプルな構造と制御が可能となり，柔軟ロボットの特徵である生 物のようなしなやかさを持ったロボットして容易に小型・軽量化にできるものと考える．まず，柔軟なロボット はアクチュエータに依存することから， ロボットの構造材料との組み合わせを考慮したアクチュエータの検討が 必要となる. 最小限の信号処理, 寸なわち, オンオフの二值で駆動できる柔らかいアクチュエータは, 現在, 高 分子材料など多岐にわたり研究がおこなわれているが，その中でも実績があり，比較的安価で，取扱いが簡便な SMA（Shape memory alloy）材料に注目する. SMA は, 髪の毛ように細く, 低電圧駆動で比較的大きなたわみ量 が得られ，自由に曲げることができる．SMA を使用する際には，SMAのたるみを無くし，張力を一定に保つよ うな制御が必要となる。ついで, 柔軟なリンク構造と SMA アクチュエータの一体化を考えたとき, 全長に渡っ てひと繋がりの構造となる和弓に注目する．和弓のように張力を維持し，かつ，材料自身がフレキシブルに動く 素材にアクチュエータを取り付けて一組とすれば，構造兼駆動源として利用することができる．さらに，リンク 素材を丸形状から角形状にすることで，断面二次モーメントを大きくすることができ，ロボットとして構造的な 強度が向上寸るものと考える，そこで，柔軟に湾曲寸るポリエチレンプレートの薄板を用いる．また，推進力を 得て, 進行方向へと速く移動するためには, 何らかの手法によって体幹を大きく振る方法が考えられる. 例えば, 尺取虫型移動は，体幹を縮めて山を作り，上下運動を推進力に変換して移動する構造をとる．仮に，上下運動と 同時に, 前後左右, いずれの方向に体を振ることできる軽い体幹構造を加えれば, 比較的安定した機構と制御で, 方向転換が可能な柔軟移動ロボットが実現できる.

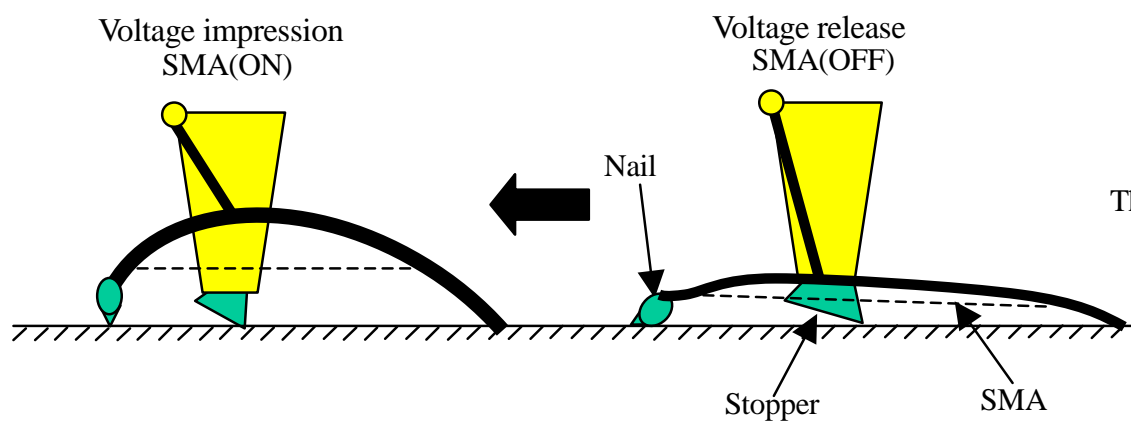

(a) Side view

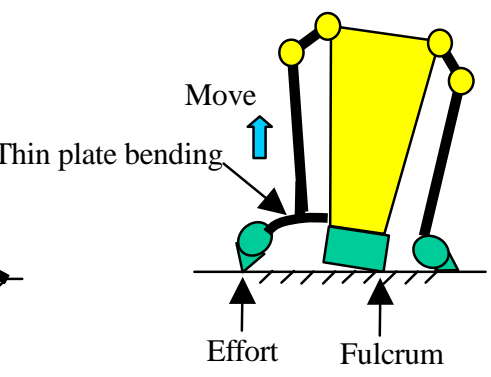

(b) Front view

Fig.3 An image of biped soft robot movement 
ここで，二脚式ソフトロボットのイメージを図 3 に示す. 構造兼駆動機構となる弓型のアクチュエータを左右 一脚づつ外側に並べ, その中央に柔軟性のある薄いポリエチレンプレートで組み上げられた立体構造を配置する. その際，外側の脚先端に「爪」，内側の立体構造の先端には「ストッパー」を設ける．前進時には，図 3 (a) の ようにアクチュエータが湾曲されると同時に爪を鉛直方向に立てることにより地面との摩擦を向上させ，後退を ストッパーによって規制する，後退時には，ストッパーが地面に接触しないようにし，左右の爪で交互に後方へ と押し出す．旋回時には，図 3(b)に示すようにストッパーの一角を支点，爪先端を力点として回転モーメントを 得る.このように左右の脚形状を ON-OFF 信号タイミングによって調整しながら動作モードを促進させる.

\section{$2 \cdot 3$ 構成要素}

製作した二脚式ソフトロボットの概要を図 4 に, ロボットの仕様を表 1 に示す. 本ロボットは(1)FFPアクチュ エータ(2)腹部 (ストッパー) (3)ボディ(4)接合部プレート(5)ジョイントプレートのユニットで構成されている. 以 下にそれぞれの部品の役割を説明する.

(1)FFPアクチュエータは， ロボットの駆動源であり，中央にプーリを取り付ける事によって，SMAのテンシ ヨンを維持している，それぞれ右脚，左脚として，左右のジョイントプレートに接続される.

(2)腹部 (ストッパー) は，電圧印加時にボディが地面から離れた時には，前方にボディを傾かせるおもりとし ての役割があり，旋回の際には回転中心となる.また，印加・解除時に，ボディが地面に支持されたとき， ロボットが後方に下がらないようにするためのすべり止めの役割がある.

(3)ボディは, 形状を逆四角錐台形とすることで岡性を高めている. そして, 水平面に対して図 4 に示す $\theta 1$ を 約 $125\left[^{\circ}\right], \quad \theta 2$ を約 $11\left[^{\circ}\right]$ 付近の角度で配置することにより, 印加した際にストッパーを前後に重心移動させ

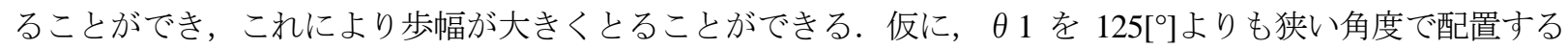
と両脚の FFP アクチュエータが地面に接地できず, 適切なたわみ量が得られない. 逆に, 広い角度で配置す るとストッパーと爪の摩擦が増して移動が困難となる．同様に，０２を 11[ ${ }^{\circ}$ の角度よりも狭くすると FFP クチュエータが地面に接地できず，広くするとストッパーが地面に支持しない状態となり，それぞれの役割 が果たせなくなるので注意が必要である.

(4)接合部プレートは, 左右の脚をボディに干渉しないようにする役割がある. また，ボディと FFPアクチュー タとの幅間隔および 2 個の FFPアクチュエータを確実に地面に接地させるための調整要素を担う。

(5)ジョイントプレートは，脚部とボディをつなぐ役割がある．脚部とボディの高さ，幅を調整する接合プレー トに対して，ジョイントプレートは，アクチュエータの前後方向の取り付け位置を調整する役割を担う.

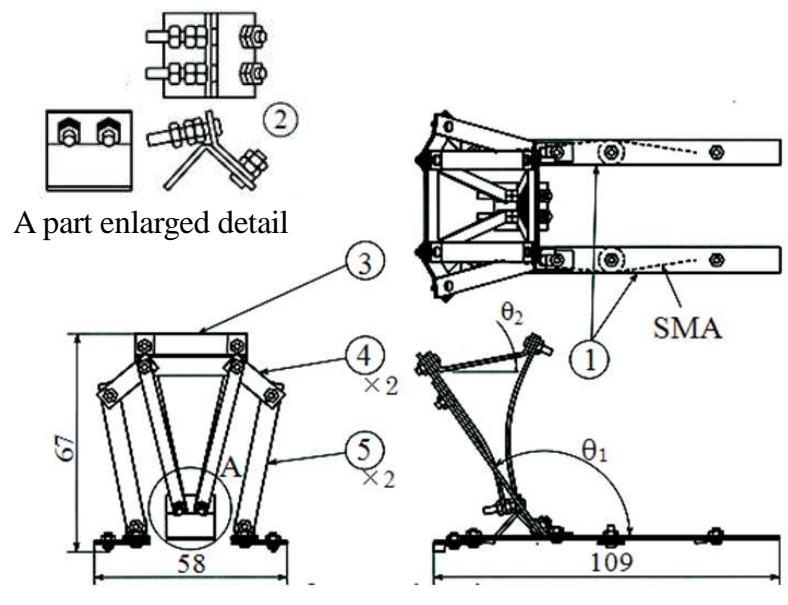

Table 1 Soft Biped Robot specifications

Fig.4 Outline figure of biped soft robot

\section{$2 \cdot 4$ 爪付きの FFP アクチュエータ}

本論文で用いている FFPアクチュエータ（Flexible Flat Plate Actuator と呼ぶ）を図 5 に示す. 厚さ $0.35[\mathrm{~mm}]$ の 薄いポリエチレンプレートに駆動源となる SMA（形状記憶合金）を組み合わせ，電圧印加・解除時の SMA の収 
縮・復元から薄板のたわみ量を獲得し，これをロボットの推進力へと変換する屈曲型のアクチュエータである. FFP アクチュエータは，ポリエチレンプレート(全長 $100[\mathrm{~mm}] \times$ 全幅 $8[\mathrm{~mm}] \times$ 厚さ $0.35[\mathrm{~mm}]$ ) と SMA(線形 $\varphi 0.075[\mathrm{~mm}] \times$ 全長 $65[\mathrm{~mm}])$ を組み合わせた約 $1[\mathrm{~g}]$ と軽量柔軟なアクチュエータとして製作している. ポリエチレン プレートは，三菱樹脂株式会社製で，ヤング率 $E: 4.0[\mathrm{Gpa}$ ，ポアソン比 $\boldsymbol{v} 0.44$ である. 使用可能温度範囲は約 203[K] 423[K] と幅広く, プレートの衝撃強さは軟質ポリエチレンの約 10 倍, そして, 延伸硬質ポリ塩化ビニル の約 1.5 倍の強度を持つ. SMA は，市販で購入できるトキ・コーポレーション社製の BMF75（線形 $\phi 0.075[\mathrm{~mm}]$ $\times 65[\mathrm{~mm}]$ ）を用いている. 現在, 研究が進められている高温形状記憶合金 ${ }^{(1)}$ などを採用することができれば，使 用する温度環境の拡大も見込めるものと想定している．筆者はこれまでに小型化・軽量化・簡略化の可能性が高 く, 目的に応じて改良しやすいアクチュエータとして座屈機構に注目し, 安価な SMA を採用している. また, 現状として, SMA は, 温度ヒステリシスなどの問題があるため, これを軽減したアクチュエータとして改良して きている ${ }^{(12)}$. ここで，このアクチュエータのステップ応答における挙動特性を図 6 に示す. FFPアクチュエータ のたわみ量 $\delta$ (図 7)は, 約 1 秒間の電圧印加で, 最大約 12[mm]のたわみ量を得ることができる. 一方で, 開発に おいては，二入出力二脚駆動によって，ロボットの前進，後退，旋回の実現を目指している．例えば，FFPアク チュエータの前端部に爪がついていない場合は, 前進はできるが, 後退や旋回に必要な回転モーメントが得られ ずに方向転換が難しい，そこで，小さな体で素早く移動できる昆虫に注目した．カブトムシやゴキブリなどの昆 虫は, 足先の爪やパッドなどを利用し, 小型ながらも前後左右への移動を可能としている(13). こうした研究を七 ントに，アクチュエータの先端に爪を模した機構を取り付ければ，後退の場合は，片側のアクチュエータの先端 を回転中心，旋回の場合は，腹部の接点を回転中心として，方向転換ができるものと考えた：こうして，左右 2 脚のアクチュエータの先端にスイングプレートの爪を約 45[]の角度で外側に向けて取り付けている.

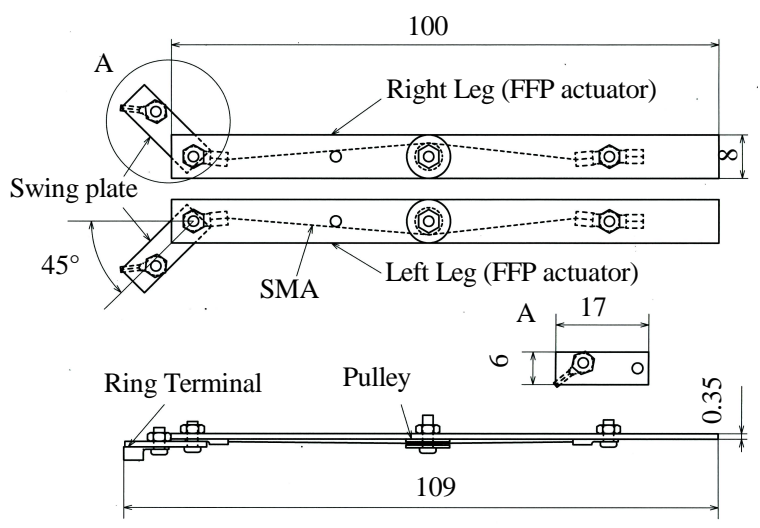

Fig.5 Outline figure of FFP actuator with nail

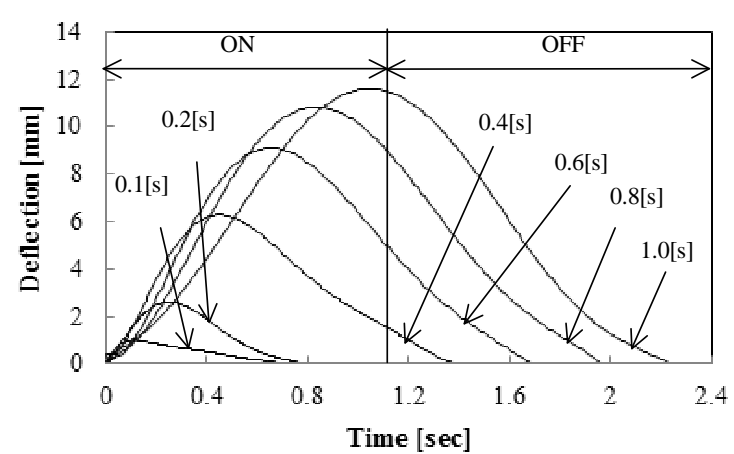

Fig.6 Time response of FFP actuator

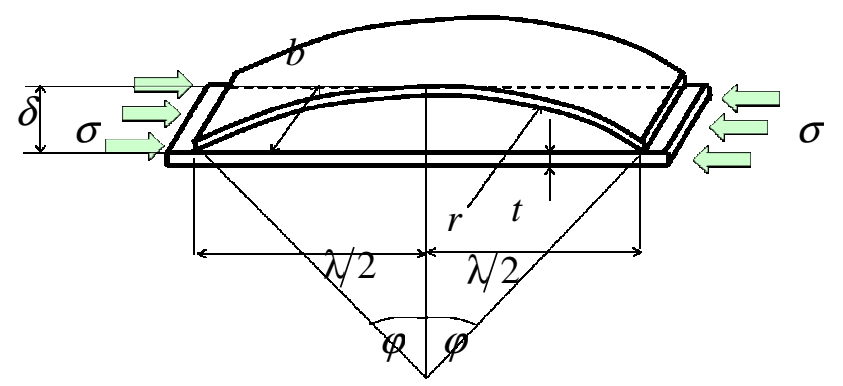

Fig.7 Flexure of thin plate ( Displacement of FFP actuator)

さて, FFPアクチュエータは, 約 1 秒間の電圧印加で, 最大 $12[\mathrm{~mm}]$ のたわみ量を得ることができるが, この時 の曲率半径 $r$ は, 約 $110[\mathrm{~mm}]$ である. 仮に, たわみ量が小さい（薄板の曲率半径が大きい）と中央のボディを地 面から数ミリ浮上，支持させながら移動することは可能であるが，体幹の振り幅が小さいため歩行速度に支障を 
きたす，逆に，たわみ量が大きい（薄板の曲率半径が小さい）と体幹が左右方向に大きく傾き，バランスを崩し て転倒する. したがって, 適切なたわみ量 (曲率半径) を確保できるような構造をとることが望まれる.ここで, 図 7 のような長さ $\lambda$, 幅 $b$, 板厚 $t$ の薄い矩形プレートを考える. この長手方向に圧縮応力 $\sigma$ が加わるとき, 座 屈応力を越えるとプレートは弾性座屈を起こす. 材料のヤング率 $E$, ポアソン比 $v$ とすると, 座屈応力は $\sigma_{y}$ は, 以下の式で求められる.

$$
\begin{aligned}
& \sigma_{y}=k \sigma_{e} \\
& \sigma_{e}=\frac{\pi^{2} E}{12\left(1-v^{2}\right)}\left(\frac{t}{b}\right)^{2}
\end{aligned}
$$

$k$ は座屈応力係数であり, 拘束条件により異なる值である. ここで, プレートのたわみ量 $\delta$ と曲率 $\rho$ との関係式 から曲率半径を $r$, 中心角を $2 \varphi$ とすれば,

$$
\begin{aligned}
& \sin \varphi=\frac{\frac{\lambda}{2}}{r} \\
& \cos \varphi=\frac{r-\delta}{r} \\
& \sin ^{2} \varphi+\cos ^{2}=1
\end{aligned}
$$

より

$$
\left(\frac{\frac{\lambda}{2}}{r}\right)^{2}+\left(\frac{r-\delta}{r}\right)^{2}=1
$$

したがって，プレートの曲率は

$$
\rho=\frac{1}{r}=\frac{2 \delta}{-\frac{\lambda^{2}}{4}+\delta^{2}}
$$

と求められる.

\section{3. 二脚式ソフトロボットの歩容原理}

二脚式ソフトロボットは, 前章に示した機構と入出力信号タイミングとを組み合わせることで, 前進, 後退, 左右旋回ができる．本章では，ロボットの歩容原理について述べる.

\section{$3 \cdot 1$ ON-OFF 信号タイミング}

本ロボットは, FFP アクチュエータが電圧印加によって湾曲し, 電圧解除によって復帰するまでの時間を考慮 して, 適切な入出力信号タイミングを施すことで移動する. まず, 前進, 後退, 旋回時の ON-OFF 信号タイミン グについて述べる. 図 8 に前進, 図 9 に後退, 図 10 に旋回時のそれぞれの ON-OFF 信号タイミングチャートを 示す. 図中において, $\mathrm{t}_{1}=$ 電圧印加 $\left(\mathrm{ON}\right.$ 時間), $\mathrm{t}_{2}=$ 電圧解除 $(\mathrm{OFF}$ 時間) とする. 上段は右脚，下段は左脚を表 している．ただし，旋回においては，上段，下段を入れ替えることでそれぞれの印加方向に旋回できる．図 8 に おいて, 前進時では腹部が接地面から完全に離れるまでの時間, 寸なわち $\mathrm{t}_{1}$ を $0.3[\mathrm{sec}]$ とし, 腹部が接地面から離 れた後に, ロボットが静止状態に戻るまでの時間を考慮して， $\mathrm{t}_{2}$ を $0.7[\mathrm{sec}]$ とた， $\mathrm{t}_{1}$ および $\mathrm{t}_{2}$ を同時印加・解除

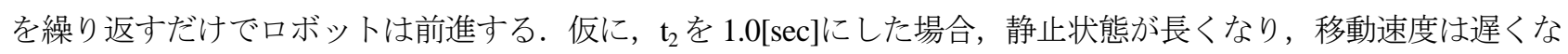


る. 図 9 の後退時では, 腹部が地面に接地するとストッパーの効果により後方に移動できない. そこで，ストッ パーを十分に浮かせたまま後方へ押し出すまでの時間を考慮して $\mathrm{t}_{1}$ および $\mathrm{t}_{2}$ を 0.75 [sec] と設定して交互に印加・ 解除寸る. 図 10 の旋回においては，ストッパーの一角を支点(回転中心) とし，アクチュエータの爪の先端から回 転モーメントを得るまでの時間を考慮して $\mathrm{t}_{1}$ を $0.7[\mathrm{sec}], \mathrm{t}_{2}$ を $0.9[\mathrm{sec}]$ と設定し, 片脚のみに, 印加・解除をおこ なう。

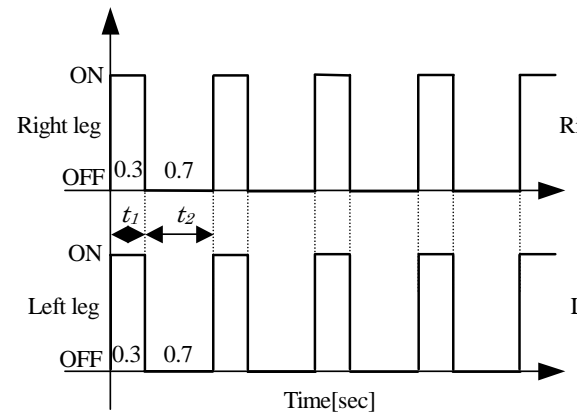

Fig.8 Timing Chart of forward

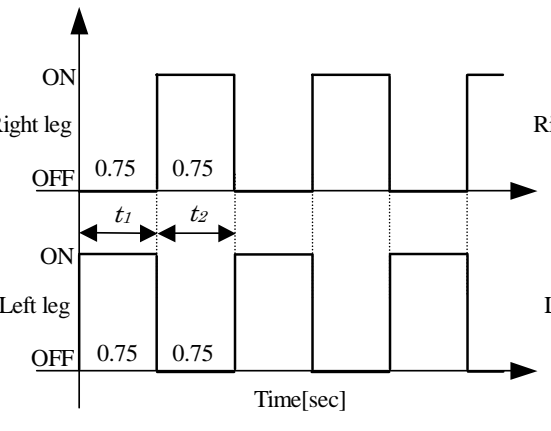

Fig.9 Timing Chart of backward

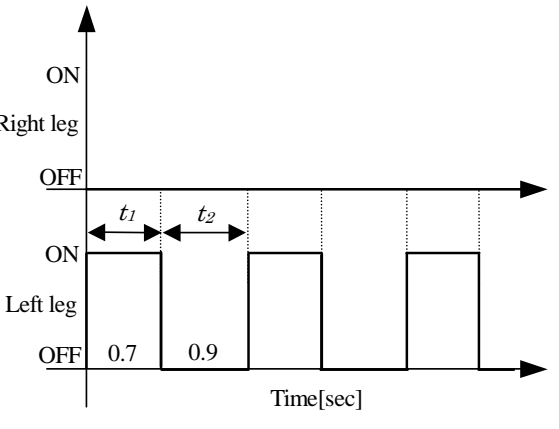

Fig.10 Timing Chart of turning

\section{$3 \cdot 2$ 歩容の概要}

次に, 図 11 にロボットの姿勢と脚の先端形状を示し, 前進・後退・旋回のそれぞれの歩容について説明する. また，本ロボットはストッパーが歩行に大きく影響している，そこで，前進·後退·旋回時のストッパーの詳細図 を示しながら説明する.

\section{(I) 前進}

図 11(a)にロボットの前進時の動作を示寸. (1)は電圧解除，(2)は両脚に電圧印加している状態である. OFF 時に は地面に支持し, ON 時には腹部が浮き上がることがわかる.ここで, 側面から見たボディの詳細を図 12 に示す. FFPアクチュエータによってボディを浮かせるためのジョイントプレートは，前方部 A で接合している．ボディ の後方部 B はジョイントプレートと接続していないため, 電圧印加で腹部が浮上した際に自重によって前方部 A を中心まわりとして前側に腹部が振れる。すなわち，Aは A'に，Bは $\mathrm{B}^{\prime} に$ 移動し，前傾姿勢から地面に対して垂 直な姿勢へと形を変える，その状態で電圧を解除すると $\mathrm{C}$ 部が $\mathrm{C}^{\prime} に \mathrm{D}$ 部が $\mathrm{D}^{\prime}$ に移動し，ストッパーが地面に支 持して静止状態となる．同時印加・同時解除を繰り返すことでロボットは腹部を振り子のように動かしながら前 進する.

\section{(II) 後退}

図 11(b)にロボットの後退時の動作を，図 13 に後退時のストッパーと爪の配置に関する詳細図を示す，たとえ ば, 右脚のアクチュエータのみに電圧印加するとアクチュエータが湾曲することでバランスを崩し, 図 11(b)(1)に 見られるように左側にロボットが傾く. 次に, 左側のアクチュエータに電圧印加しながら右側のアクチュエータ の電圧を解除すると左右が逆になり，図 11(b)(2)の状態となる。ここでは，信号タイミングによってボディを確実 に浮かせたまま, ストッパーを解除しておく. 電圧解除時には, 図 13 に示寸ように, 印加してないアクチュエー タの先を回転中心，印加を解除したアクチュエータの爪が地面を蹴る力を力点として反力を得る. これにより生 じる回転モーメントを利用して, 左右交互に電圧印加・電圧解除をすることでロボットは後退する. このように, 後退の際は, ストッパーによりロボットが前進寸るのを防ぐため, 中央のボディが浮上している状態を保持した 信号タイミングで FFPアクチュエータを駆動させることが重要である.

\section{(III) 旋回}

図 11(c)にロボットの旋回時の動作を, 図 14 に旋回時の詳細を示す. 図 11(c)(1)の静止状態から, 右脚のアクチ ユエータに電圧印加すると図 11(c)(2)のようにボディが左側に傾きながら, 図 14 のストッパーの角 A 部が地面に 接地する設計としている. 次に, 印加を解除すると角 $\mathrm{A}$ 部を回転中心, 爪先端 $\mathrm{B}$ を力点として回転モーメントを 得ることができる．電圧印加・解除を片側のアクチュエータのみに繰り返すことで旋回運動が可能となる．旋回 
では，図 15 に示すように，一周期の印加・解除，寸なわち，およそ 3 4[sec]かけて約 10[ㅜㄱ, 前方に約 3[mm]ほど 旋回移動する.

以上のように，ストッパーはロボットの移動になくてはならないものであり，前進時にはすべり摩擦によって ロボットが後退しないように地面に支持させ，後退時には前進しないようにボディを浮かせながら機能を解除寸 ることが重要であり，旋回時にはストッパーの後方部角点を回転中心となるように設計するとよい.

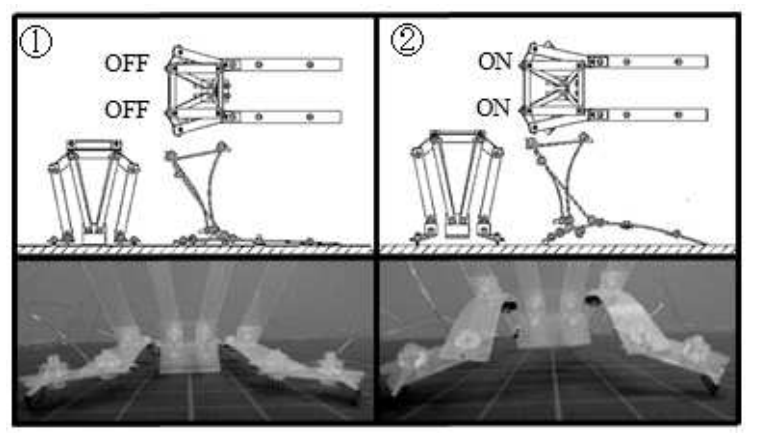

(a) Forward

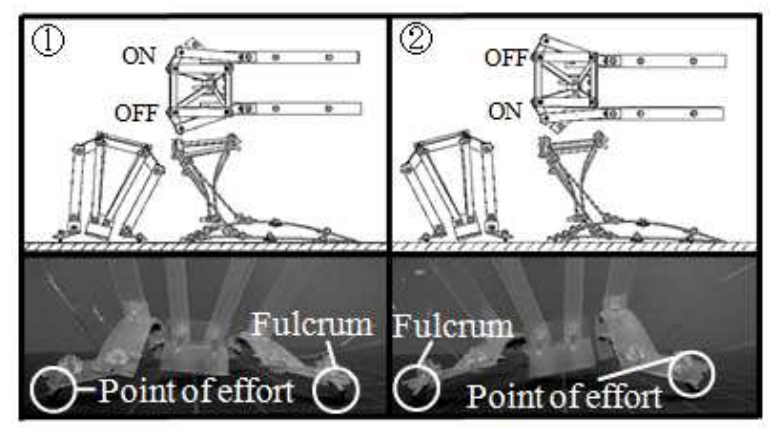

(b) Backward

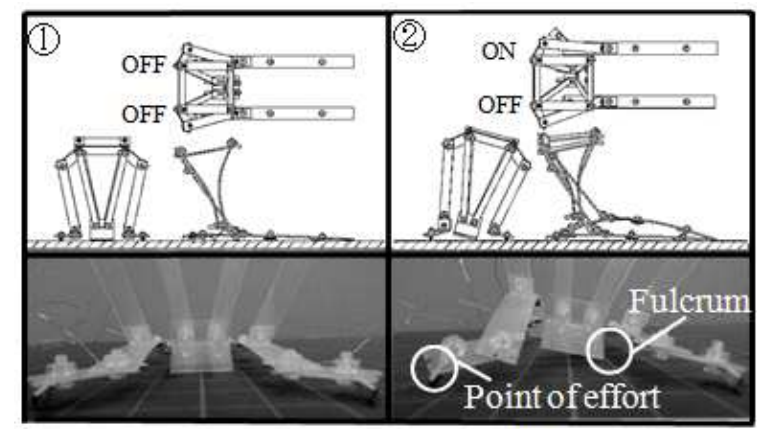

(c) Turning

Fig.11 Soft Biped Robot walking experiment

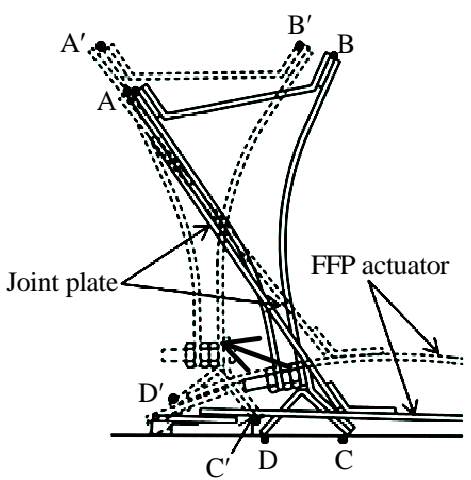

Fig.12 State of forward

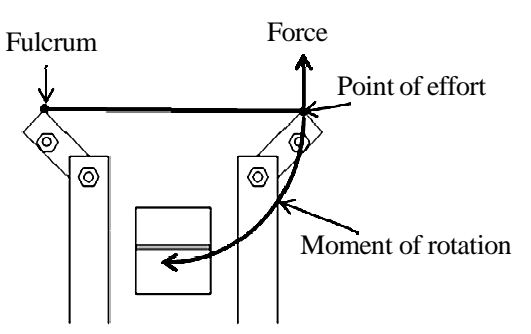

Fig.13 State of backward

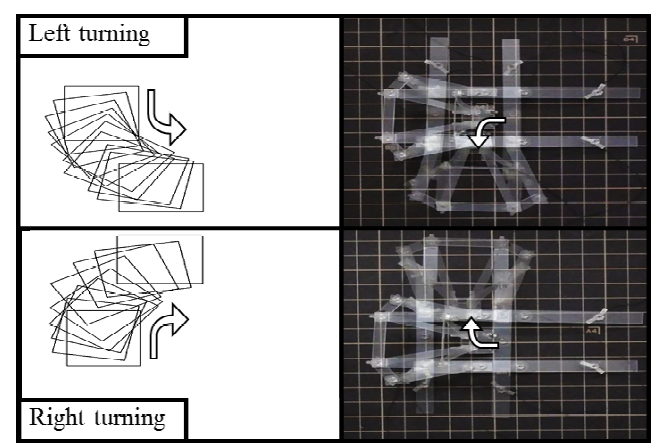

Fig.15 Gait of turning

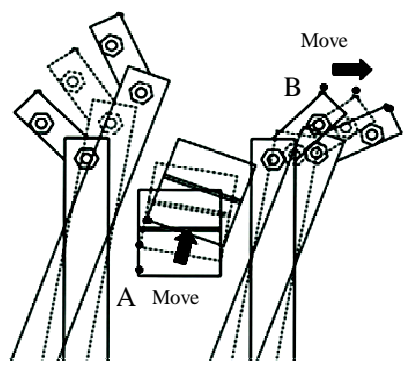

Fig.14 State of turning 


\section{4. 二脚式ソフトロボットのペイロード実験}

\section{$4 \cdot 1$ 実験概要}

本ロボットは，将来的に実用化を目指して開発をおこなっている．そこで，小型センサやバッテリーを搭載し て自立歩行させることを想定し，ペイロード実験をおこなった．ペイロード実験の概要を図 16 に示す. 実験マッ トの中央にロボットを置き, 移動距離を測定するためにスケールをロボットと並行に配置した．次にストップウ オッチを 20 秒間作動させ， ロボットを歩行させた，その様子を上方部と側面部のカメラで撮影した.

ロボットの重心が地面に対して一定の速度で移動でき,かつ一定の積載面積を確保することを確認するために, 図 17 に示すように比較的積載エリアが確保できる $\mathrm{A}$ タイプと, 重心の低い位置に負荷物を積載することを考慮 した B タイプの二つのパターンを用意した．おもりは，0.5[g]ごとに増やしていき，最終的に歩行不可能となる 重量まで測定を行った. また, SMA の残留熱による応答速度の低下を防ぐため 1 回の歩行毎に 3 分間の泠却時間 を設けた．さらに，信号タイミングはロボットに大きく影響するため，負荷物の増加に伴ってロボットが歩行で きなくなるまで一定として計測し, 前進では同時印加で $\mathrm{ON}=0.3[\mathrm{~s}], \mathrm{OFF}=0.7[\mathrm{~s}]$, 後退では交互印加で $\mathrm{ON}=0.7[\mathrm{~s}]$, $\mathrm{OFF}=0.9[\mathrm{~s}]$ とした．旋回については，速度に関する比較形態が前後移動と異なるため，今回はこの二つに焦点を 当てて実験を試みた。測定時の気温は298[K]と一定に設定した。

\section{$4 \cdot 2$ 実験結果}

図 18 および図 19 に前進と後退のペイロード実験結果を示す. 図 18 はAタイプ, 図 19 はB タイプの結果であ る. 右軸に時間, 縦軸に移動距離をとる. 図 18 の A タイプ (前進) では, $0.5[\mathrm{~g}]$ の時は移動距離が 20 秒間で $68[\mathrm{~mm}]$ 進んだ. 負荷をかけていない $0[\mathrm{~g}] （$ 移動距離 59[mm]）と比較して約 9[mm]伸びたことが確認された. しかし，そ の後, 積載量が増加するとロボットの移動距離が短くなり, $2.5[\mathrm{~g}]$ で歩行不可能となった. 次に, A タイプ (後退) では, $0.5[\mathrm{~g}]$ の時に 64[mm]と負荷をかけていない $0[\mathrm{~g}] （ 52[\mathrm{~mm}] ）$ と比較して約 $12[\mathrm{~mm}]$ 後ろに後退したことが確認 された，その後, 後退距離が低下し，4.0[g]で歩行不可能となった。一方で, 図 19 の B タイプ（前進）では, 口 ボットに負荷を加えることによって $4.5[\mathrm{~g}]$ の時に最大 $121[\mathrm{~mm}]$ と進み, その後, $5.0[\mathrm{~g}]$ では $112[\mathrm{~mm}]$ と $0[\mathrm{~g}](59[\mathrm{~mm}])$ と比較して約 2 倍ほど大きく距離を延ばした.しかし，6.0[g]になると，63[mm]と極端に移動距離が低下し，6.5[g] では $0[\mathrm{~g}]$ とほぼ同様の歩行と確認された. そして 7.0[g]で歩行不可能となった. 次に B タイプ（後退）では, $0.5[\mathrm{~g}]$ の時に $64[\mathrm{~mm}]$ と $0[\mathrm{~g}] （ 52[\mathrm{~mm}] ）$ に対して約 12[mm]距離を伸ばした．しかし，1.0[g]の時点で移動距離は $39[\mathrm{~mm}]$ に落ち，1.5[g]で歩行不可能となった。ここで，A タイプ（前進）の移動距離が伸びなかった理由について考察す る.まず, 図 20 に見られるようにロボットの上部に負荷をかけた場合, そのほぼ真下にあるアクチュエータの爪 （a 部）の摩擦が増加し，これによってストッパーの効果が得られず，ロボットの前進が難しくなったと考える. また, A タイプ (後退) では, アクチュエータに印加した際に負荷物が重くなると腹部が十分に浮き上がること ができず，後退ができなくなるものと考える．次にB タイプ（前進）について考察する．まず図 21 に見られる ように，ストッパーの真上に負荷が置かれているため，重力の方向によるストッパーの摩擦力が向上し，移動距 離が延びたものと考える. しかし, 積載量 $7[\mathrm{~g}]$ に到達するとアクチュエータに電圧印加した際に, 重みによって 腹が浮き上がらなくなるため, ロボットの前進が難しくなるものと考える．以上により，ロボットにペイロード を積載する場合は, 配置する場所によって移動速度が変化するため, 効果的に動作するような積載エリアを確保 することが望まれる.

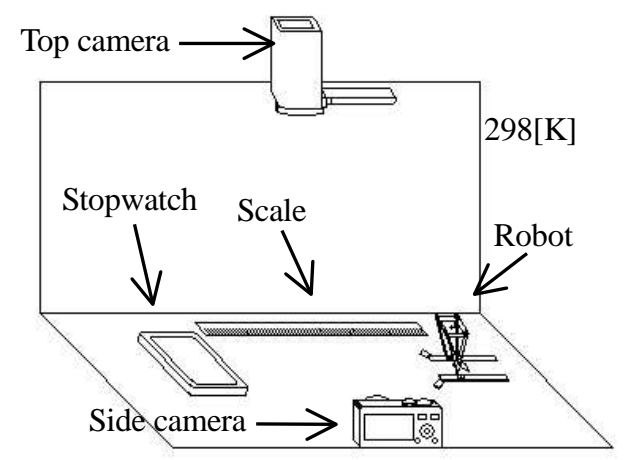

Fig.16 Overview of the payload experiment

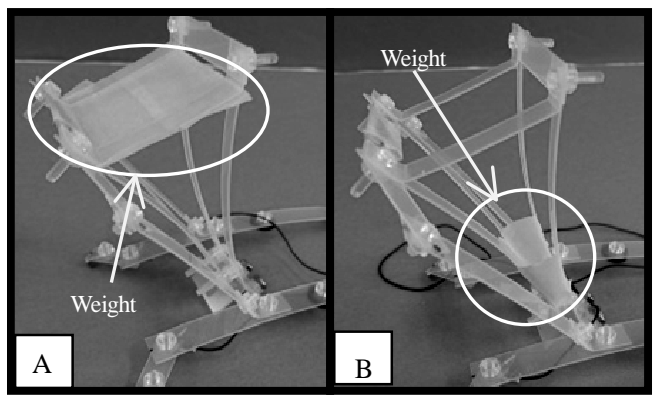

Fig.17 Payload places 


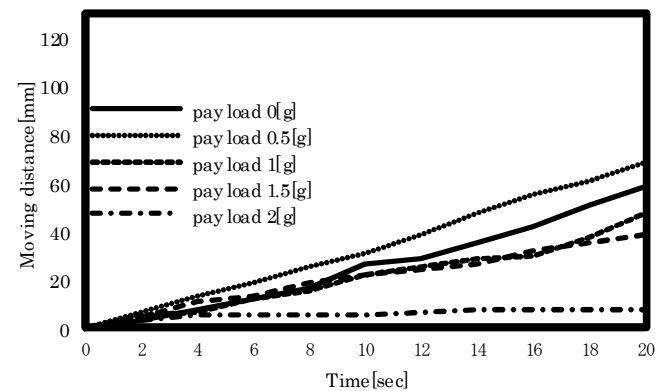

(a) Forward

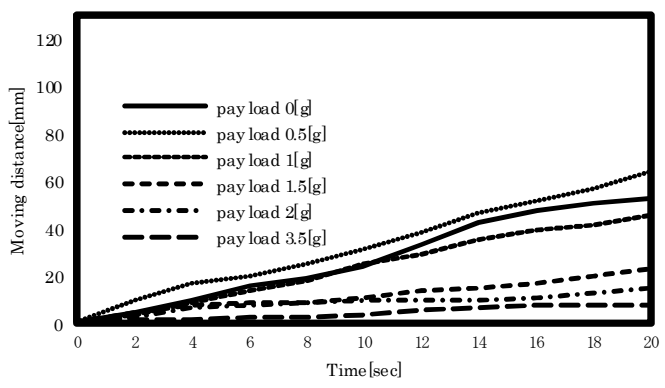

(b) Backward

Fig.18 Experimental results of the payload (A type)

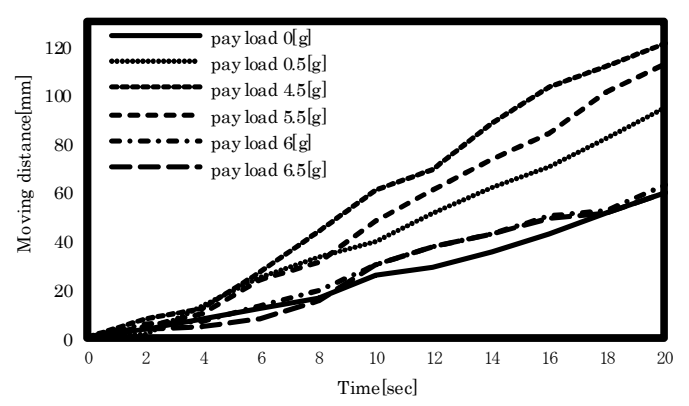

(a) Forward

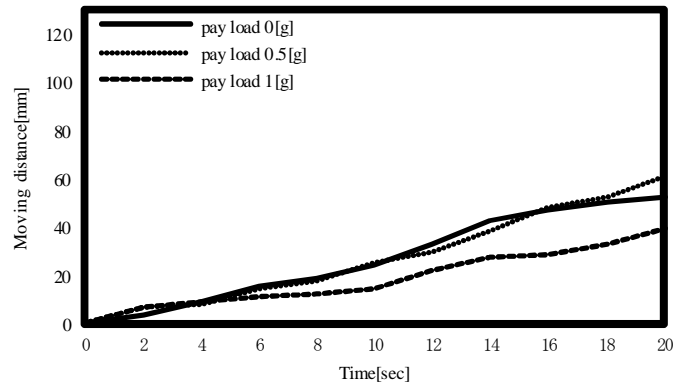

(b) Backward

Fig.19 Experimental results of the payload (B type)

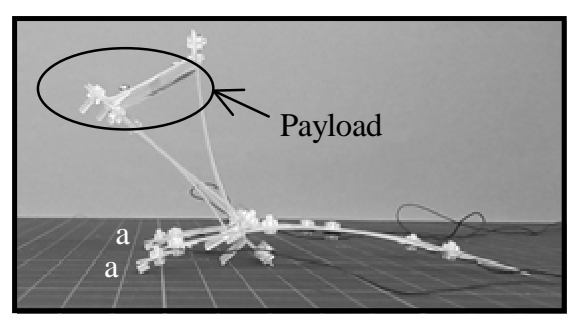

Fig.20 Experimental results of the payload (A type)

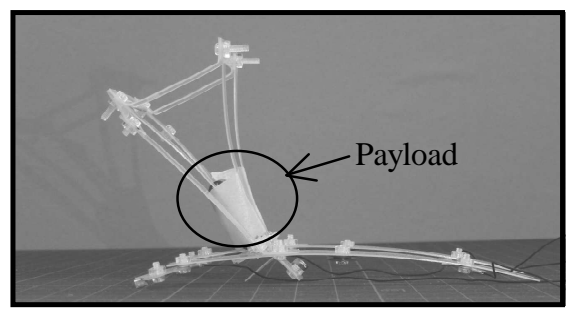

Fig.21 Experimental results of the payload (B type)

\section{5. 結 言}

本論文では，ロボットの先端部に，薄板とメガネ端子を組み合わせた爪を固定し， ON-OFF信号タイミングに よる薄板のたわみ量とボディ下部のストッパーを巧みに利用して， 2 入出力 2 脚駆動で前後，左右旋回するソフ トロボットを開発した。本論で得られた結果を以下にまとめる.

（1）ロボットの構造は，薄板のポリエチレンプレートを逆四角錐台形に組み上げることによりボディの岡性を 高め, かつ柔軟性構造を可能とした。 また, 左右 2 脚のアクチュエータの先端に爪, 逆四角錐台形の下部 にストッパー付加することで，前後・左右旋回ができる.

(2) ロボットの信号タイミングは, 前進では, $\mathrm{ON}=0.3[\mathrm{sec}], \mathrm{OFF}=0.7[\mathrm{sec}]$ の同時印加・解除, 後退時では $\mathrm{ON}=0.75[\mathrm{sec}], \mathrm{OFF}=0.75[\mathrm{sec}]$ 交互印加・解除, 旋回時では $\mathrm{ON}=0.7[\mathrm{sec}], \mathrm{OFF}=0.9[\mathrm{sec}$ ]の片脚印加・解除を 適切に行うことで動作を達成できる.

（3）アクチュエータの先端に爪を $45\left[^{\circ}\right]$ の角度で外側に向けて配置し, ストッパーは, 前進時にはロボットが後 退しないように地面に支持させ, 後退時には前進しないように浮かせる必要がある. また, 旋回時には回 転中心となるように設計するとよい．

（4）ペイロード実験では，ロボットと同様の可搬質量(約 4.7[g])を確認した. しかし, 配置する場所によって移 動速度が变化するため, 効果的に動作するような積載エリアを確保することが望まれる. 
本論文では，SMA 駆動の二脚式ソフトロボットについて，ロボットの基本構成，基本原理，基本動作実験（移 動実験とペイロード）を中心に述べ，ロボティクス分野の新しい可能性を示した．しかし，ロボットは，移動面 の凹凸や爪の変化（取り付け角度, 形状）など，それぞれのパラメータが変更されたときに移動特性に大きな影 響を与えるものと考える. 本ロボット設計の最適化や妥当性については，これらの課題をまずは具体的に調査・ 検討して，構造と制御の両面から明らかにしていく予定である.

\section{文献}

（1）大武美保子, “軟体動物型ゲルロボットをつくる - 電場応答性高分子ゲルを用いた柔軟ロボットの設計 - ”, 未来 材料, Vol.8, No. 12 (2008), pp.2-5.

(2) 原雄介, 前田真吾, 橋本周司, 吉田亮, “自励振動ゲルの設計と機能材料への展望”, 機能材料, Vol.27, No.2 (2007), pp.5-514.

（3）中井博之, 星野由紀子, 稲葉雅幸, 井上博允, “軟化変形ロボットの研究 - 低融点金属の相変化を用いた形状変形 適応ロボットの実現 - ”, 日本ロボット学会誌, Vol.20, No.6(2000), pp.69-74.

(4) 柴田瑞穂, 寺師和真, 仲瀬洸男, 平井慎一, “テンセグリティ型多面体ロボットの転がり移動”, 日本機会学会口 ボティクス・メカトロニクス講演会講演論文集, Vol. 2009(2009), pp.AC2Q-04.

(5) 塩津あゆみ, 平井慎一, “IPMCアクチュエータによる柔軟ロボットの移動”, 日本機械学会ロボティクス・メカト ロニクス講演会講演概要集, Vol. 2006(2006), pp.1P1-B26.

(6) Stephen, A.M., Robert, F., Shepherd, Sen Wai Kwok., Adam A. Stokes., Alex Nemiroski., George M. Whitesides., “Camouflage and Display for Soft Machines", Journal of Science 17 August 2012, Vol. 337, No. 6096(2012), pp. 828-832.

(7) 西田麻美, “SMA と柔軟プレートを組み合わせた四脚移動ロボットの開発”, 精密工学会誌, 精密工学会, Vol.78, No.11(2012), pp.1004-1008.

(8) 清田恭平, 深井雄大, 矢吹彗介, 西田麻美, “FFP アクチュエータを用いた腹ばい型柔軟歩行ロボットの脚部構 造の検討”，計測自動制御学会システムインテグレーション部門講演会（SI2011）講演論文集, pp.333-334.

(9) 安藤勇太, 比留間奨仁, 成瀬圭介, 竹下優, 西田麻美, “FFP アクチュエータの構造とその曲率変化による動作特 性の評価”，日本機械学会ロボティクス・メカトロニクス講演会講演論文集，Vol. 2012(2012),pp.2A2-C07.

(10) 村岡遊, 高橋稔幸, 谷村健太, 西田麻美, “多方向への移動を可能としたソフト二足歩行ロボット”, 日本機械学会 ロボティクス・メカトロニクス講演会講演論文集，Vol. 2013(2013), pp.1P1-F01.

（11）金熙榮，奥津和俊，宮崎修一，“Ti-Ni 基および Ni-Al 基高温形状記憶合金の変態挙動”, 金属学会会報一まてりあ, Vol.42, No.9(2003), pp.655-661.

(12) 西田麻美, “ソフト歩行ロボットに関する FFPアクチュエータの応答速度の向上”, 関東学院大学工学部研究報告, No.56-1(2012), pp.71-76.

(13) Clement,C.J. and Federle,W.“ Pushing versus pulling division of labour between tarsal attachment pads in cockroaches”, Proceedings of the Royal Society, B275 (2008), pp.1329-1336. 